\title{
Using Flow Cytometry to Quantify Microbial Heterogeneity
}

\author{
Hazel M. Davey^ and Michael K. Winson \\ Institute of Biological Sciences, University of Wales, \\ Aberystwyth, Ceredigion, SY23 3DD Wales, U.K.
}

\begin{abstract}
Flow cytometry is a powerful technique for the study of single cells, and thus it is of particular utility in the study of heterogeneity in microbial populations. This review seeks to highlight the role of flow cytometric analyses in studies of microbial heterogeneity, drawing wherever possible on recently published research articles. Whilst microbial heterogeneity is well documented in both natural and laboratory environments, the underlying causes are less well understood. Possible sources for the heterogeneity that is observed in microbial systems are discussed, together with the flow cytometric tools that aid its study. The role of flow cytometry in molecular biology is discussed with reference to gene reporter systems, which enable heterogeneity of gene expression to be monitored. With the recent sequencing of a variety of microbial genomes, it is anticipated that flow cytometry will have an increasing role to play in studying the effects of gene expression and mutation on heterogeneity, and in resolving the interactions of genetics and physiology.
\end{abstract}

\section{Introduction}

Cytometry is a technique familiar to all biologists, and involves the measurement of cells, typically by light microscopy. By extension, flow cytometry involves making measurements on cells as they flow in single file past an array of detectors. In a typical flow cytometer (Shapiro, 1995), individual particles pass through an illumination zone and detectors measure the magnitude of a pulse representing the extent of light scattered or the intensity of fluorescence emitted. The optical arrangement of a typical flow cytometer is illustrated in Figure 1.

While scattered light provides information on the size and granularity of the scattering particles, the real power of the method comes from making measurements of the fluorescence intensity of individual cells. There are several sources of cellular fluorescence, including the presence of autofluorescent pigments, the addition of fluorescent stains that bind to (or react with) particular molecules and/or the addition of specific labels such as fluorescently-tagged antibodies, oligonucleotides or lectins

Flow cytometry has several advantages over

*For correspondence. Email hlr@aber.ac.uk; Tel. +44 (0) 1970 621829; Fax. +44 (0) 1970622307. conventional cytometry. Typical commercial instruments make measurements at rates of up to 1000 cells. $\mathrm{sec}^{-1}$, whilst specialised high-throughput instruments can make measurements at rates in excess of 25,000 cells. sec ${ }^{-1}$. Thus, flow cytometric data sets often represent 10,000 to 500,000 cells for a given population leading to statistically significant results (cf. measurements made by light or fluorescence microscopy on at best a few hundred cells). By analysing many more cells than would be possible by conventional cytometry, rare cell types are more likely to be detected. Secondly, since flow cytometry uses very sensitive electronic detectors to measure the intensity of scattered light or fluorescence at a given wavelength, different intensities of light scatter / fluorescence can be distinguished. By calibrating an instrument with samples of known size or fluorescent intensity, it is possible to obtain quantitative measurements of sample heterogeneity. Thirdly, flow cytometric measurements can be made on several different characteristics of each cell. Such multiparametric measurements are useful because they allow one to correlate the different characteristics and thus define subpopulations and/or distinguish between different cell types. Typical commercial flow cytometers allow 5-10 different parameters (e.g. size, protein content, DNA content, lipid content, antigenic properties, enzyme activity etc) to be collected for each cell, allowing a multidimensional representation of a population to be obtained. Finally, since measurements are made on single cells, heterogeneity within the population can be detected and quantified. Thus, flow cytometric analysis enables the investigator to build up a multidimensional representation of the individual cells within a population. Figure 2 shows the distribution of rhodamine 123 uptake in an exponential culture of $E$. coli. It can be seen that even in a controlled laboratory culture there are almost three orders of magnitude difference in fluorescence intensity between the dimmest and brightest cells.

Whilst all flow cytometers have the advantages described above, some specialised instruments (cell sorters) are able to physically separate cells on the basis of user-defined characteristics. Cells may be bulk-sorted for biochemical analysis in order to gain an understanding of how different cohorts of cells vary with respect to a character of interest (e.g. Howlett and Avery, 1999). Alternatively, individual cells may be sorted onto microscope slides for confirmation of their identities (Campbell et al., 1993). A powerful alternative is to sort single cells into microtitre plates or onto agar plates for recovery (Nebe-von-Caron et al., 1998; Davey et al., 1999b). Providing that appropriate cell staining and sample preparation methods have been used that maintain viability, sorted cells can be grown to give clonal colonies or broth suspensions. This has particular advantages in molecular biology for isolating mutants, and is also of use in strain improvement programmes in industrial microbiology (Betz et al., 1984; Bell et al., 1998). 


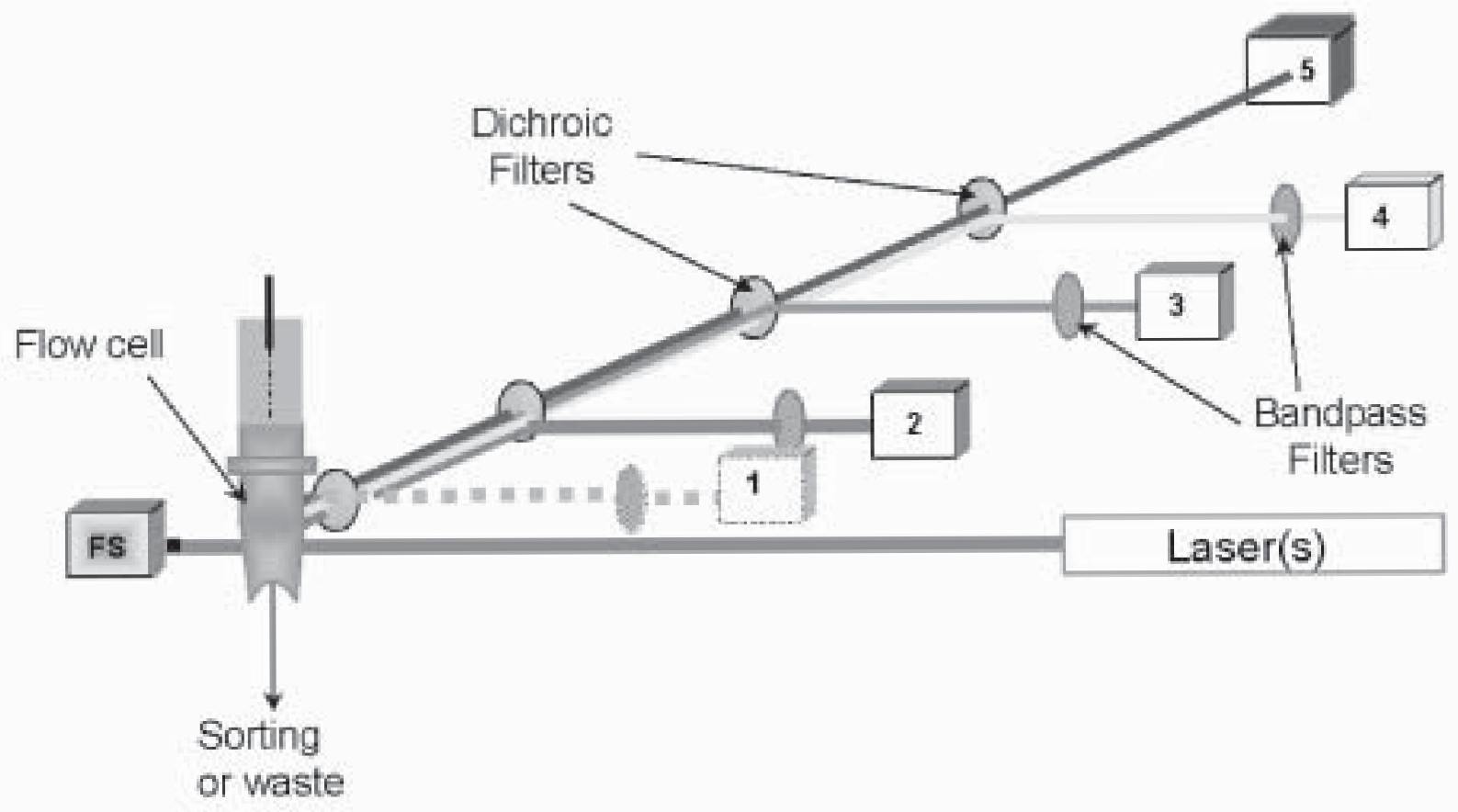

Figure 1. The optical system of a flow cytometer is composed of one or more light sources, together with a series of filters and detectors. Following interaction with cells, the scattered and fluorescent light is transferred from the measuring point to the detectors. Dichroic filters are selective mirrors that allow transmission of long wavelengths while reflecting short wavelengths. Bandpass filters allow light of a specific wavelength, or a narrow band of wavelengths, to pass through. By using appropriate filters fluorescent light is separated into discrete bands related to different fluorescent compounds present within or on the cells.

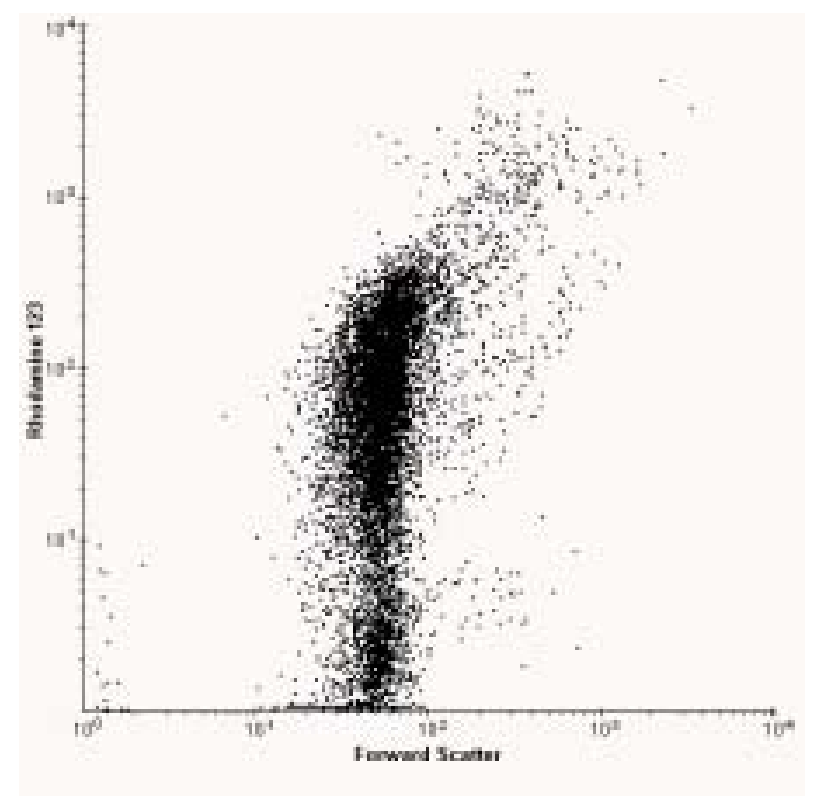

Figure 2. Dual parameter dotplot showing the distributions of forward light scatter (cell size) and rhodamine 123 uptake in an exponential culture of Escherichia coli. E. coli were sampled from a flask culture after 6 hours cultivation and were in exponential phase as judged by O.D. measurement. Rhodamine 123 was added to a final concentration of $0.3 \mu \mathrm{M}$ and the cells were incubated for 30 minutes at room temperature prior to analysis.

\section{Heterogeneity in Microorganisms}

Heterogeneity in microorganisms is widely reported. For example, the exposure of an axenic laboratory culture to a moderate stress (e.g. antimicrobial compound, UV, heat etc) may lead to a loss of culturability of a proportion of the cells and this is utilised as the basis for the LD50 method of testing drug effectiveness. In applied environmental microbiology, survival may be an unwanted problem when e.g. microbes survive wastewater treatments designed to eradicate them. Alternatively, survival could be used to our advantage when attempting to isolate useful strains for the bioremediation of contaminated soils.

Although heterogeneity itself is well documented, the mechanisms that underlie it are not well understood. Historically, our ability to study, measure and explain the loss of culturability of some members of a population has been frustrated by the limitations of traditional microbiological methods, which involve the study of populations rather than individuals; such methods necessarily obscure heterogeneity (Shapiro, 2000). In comparison, since flow cytometry involves the study of single cells, it is an ideal method for studying heterogeneous populations. Differences between members of a population may be detectable by flow cytometry. These may include differences in cell size / DNA content / antigenic properties etc and will enable flow cytometry to be used to detect, characterise and/or isolate these individuals directly. In other cases, it may be possible to use flow cytometry 
with a fluorescent reporter system to determine levels of gene expression (see later). However, before introducing flow cytometric methods for studying heterogeneity, we first discuss some of the possible sources of heterogeneity in microbial populations.

\section{Mixed, Natural Samples}

In nature, microorganisms often co-exist with other microbial and non-microbial species. Whilst it is common laboratory practice to study axenic cultures, it may be beneficial for the environmental microbiologist to study microbial consortia and other mixed populations in order to observe and understand interactions between different organisms. Mixed populations represent heterogeneity in its broadest sense and individual populations may fluctuate as a result of competition between different species. Competition may lead to reduction in heterogeneity (biodiversity). Methods that improve our understanding of the interactions between microorganisms and of the role that environmental conditions may play in reduction of biodiversity, are currently of much scientific and general interest as these factors may lead to loss of biotechnologically-valuable organisms (Bull et al., 2000).

Flow cytometry is a technique with great potential in such studies, and has recently been used to identify subgroups of bacterioplankton (Andreatta et al., 2001). By using flow cytometric techniques to analyse the effects of protozoan grazing on each of the subpopulations, a more detailed and meaningful interpretation of community structure and ecology was achieved than would have been possible from studies of the population as a whole. For reasons of ease of sample preparation flow cytometry has been used to greatest effect in studies of aquatic systems (Vives-Rego et al., 2000), where it has been instrumental in the detection of a previously unknown marine picoeucaryote (Chrétiennot-Dinet et al., 1995).

\section{Mutation}

Changes in DNA sequence may occur through a combination of errors in DNA replication and failures in DNA repair mechanisms. The chance of a point mutation arising is considered to be about $10^{-8}$ per cell division (Paustian, 2002). It is common to use one culture as the source for inoculating a subsequent culture. Over the course of several subculture steps it is clear that mutational variability will contribute to heterogeneity in the population. If selection pressure is a factor in a given environment then heterogeneity due to mutation may be amplified.

\section{Cell Cycle and DNA Replication}

Analysis of microbial cells is usually performed using nonsynchronous populations, as this avoids any potential perturbation to normal growth that may be brought about by the synchronisation process. Consequently, data obtained from a population of cells are "time averaged" over an interval equivalent to the division time (Lloyd, 1993). The expression of a proportion of an organism's genes may be expected to vary with progression through the cell cycle and thus heterogeneity will be observed in such samples. Unlike eukaryotes, bacteria have the capacity to initiate a new cycle of DNA replication before the previous cycle has been completed. This leads to genes closest to the origin of replication being present in higher copy number ( $2 x, 4 x$ etc) and this will have consequences for cellular regulation mechanisms.

\section{Plasmids and Other Additional Genetic Material}

Cells may acquire extra genetic material in the form of plasmids, transposons or bacteriophage by transformation, conjugation or transduction; these cells may thus exhibit a different gene expression profile to cells that lack the additional genetic material. In some cases this will result in morphological or enzymatic changes that are amenable to detection by flow cytometry. The replication of plasmids, and the expression of genes encoded by them, puts an additional metabolic load on the cell and this alone may be sufficient to cause changes in cell physiology between plasmid-bearing and plasmid-free members of a population (Goodacre and Kell, 1993). By using a flow cytometricallydetectable marker encoded by a gene on the plasmid (Maksimow et al., 2002), copy number and plasmid loss can be monitored at the single-cell level.

Bacillus anthracis (the causative agent of anthrax), carries two large plasmids (Okinaka et al., 1999). Plasmid pX01 carries three toxin genes and plasmid pX02 carries genes that make polymers of glutamic acid, which bind to the cell surface to inhibit phagocytosis. Strains lacking either plasmid are not virulent thus demonstrating the dramatic physiological change that plasmid-presence and plasmid-loss can involve for an organism.

\section{Local Environment}

Even seemingly homogenous environments provided for growth in the laboratory may in fact be divided into a variety of niches. In a simple test tube culture, differences in gene expression may be expected in cells from aerobic, microaerophilic and anaerobic layers; in addition cells growing on the surface of the glass or plastic tube may be physiologically distinct from those that have grown suspended in liquid. A sample from such a culture will thus result in a heterogeneous mixture of cells.

In industrial-scale fermentors, a variety of environments will also be present. Irrespective of fermentor design, stirring will be imperfect and higher concentrations of nutrients will occur, at least briefly, near feed lines. Such problems often manifest themselves during the scale-up of research experiments to industrial production volumes (Hewitt et al., 2000).

\section{Flow Cytometric Analysis of Heterogeneity}

As described above, flow cytometry offers great potential for the study of heterogeneity. Whilst the study of individual cells rather than populations is an essential factor, the multiparametric nature of flow cytometric measurements also offers interesting possibilities. For each parameter, data are collected and "binned" in software to produce histograms representing e.g. frequency of occurrence of cells with a particular fluorescence intensity versus the (arbitrary) fluorescence intensity value. Gates or thresholds can be set up on one or more of these histograms to limit the data collected to a subset of the sample. This can be 


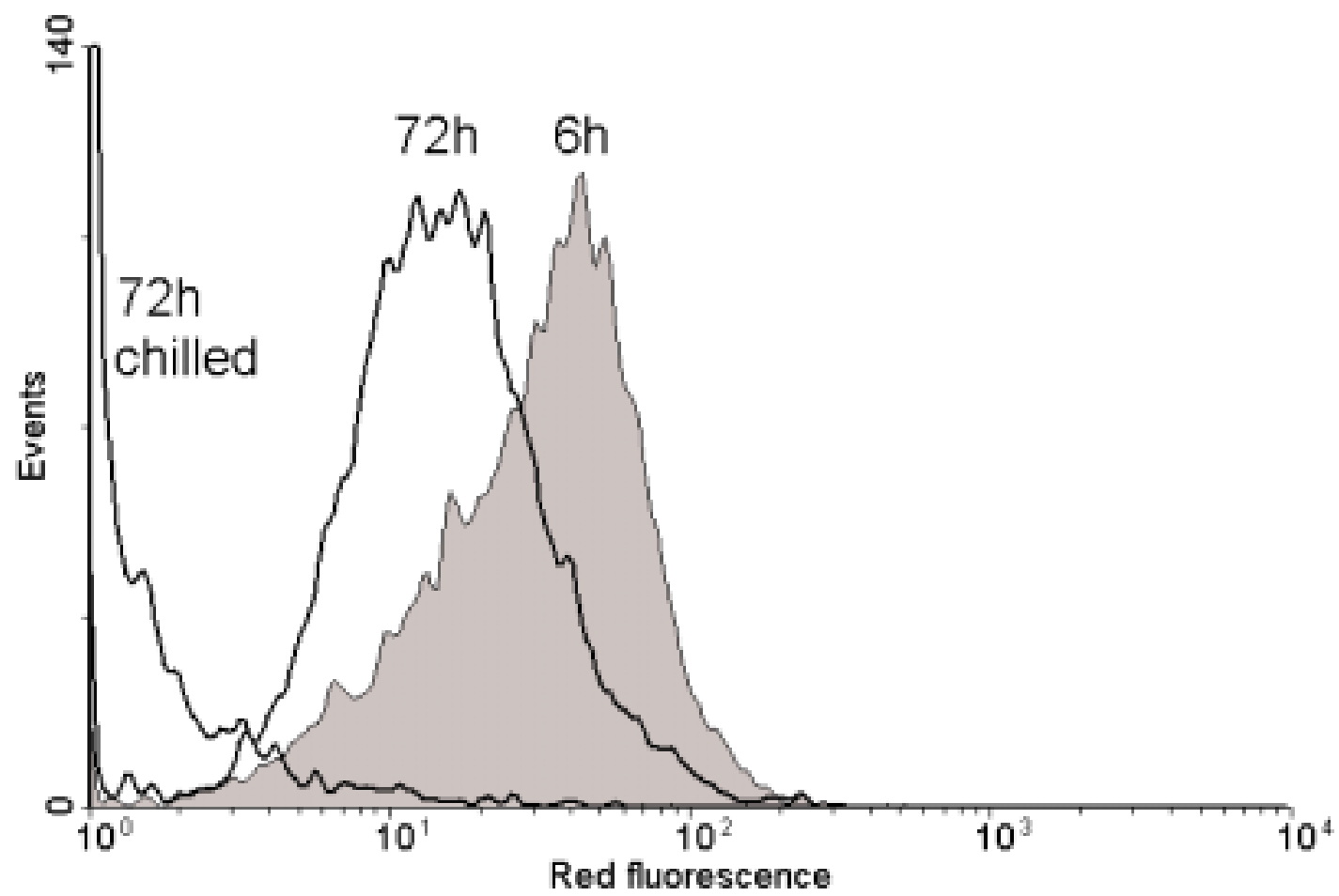

Figure 3. Flow cytometric analysis of $E$. coli following incubation with $100 \mu \mathrm{M}$ carboxy-naphthofluorescein diacetate (CNFDA) for 30 minutes at $37^{\circ} \mathrm{C}$. Viable cells cleave the non-fluorescent CNFDA molecule, liberating carboxy-naphthofluorescein. After 6 hours of culture, the cells were viable and capable of cleaving the CNFDA. After prolonged culture $\left(72 \mathrm{~h}\right.$ ), the fluorescence was reduced. Exposure of the $72 \mathrm{~h}$ culture to a cold shock (stored for $2 \mathrm{~h}$ at $4^{\circ} \mathrm{C}$, then incubated with CNFDA as above) reduces the fluorescence still further. Dead cells (fixed with $70 \%$ ethanol) gave similar results to the chilled cells (not shown).

extremely useful when analysing environmental samples which may contain non-biological particulate matter.

Freeware and commercial software packages exist for analysis of flow cytometric data (many are available from http://flowcyt.cyto.purdue.edu/flowcyt/software/ Catalog.htm) and these permit visual examination of dualor triple- parameter plots. These may reveal that cells that were classified with the same intensity value for one parameter have a distribution of intensity values in a second or subsequent parameter. The more parameters that one measures, the more sub-classes one is likely to require to describe the data collected from the cell population. However, while this is advantageous in terms of distinguishing between cell types, the data rapidly become difficult to visualise and advanced data processing techniques are often required to reduce the dimensionality of the data (see e.g. Davey et al., 1999a).

\section{Fluorescent Stains}

Whilst measurements of heterogeneity in cell size and autofluorescence alone may be useful in some situations (e.g. identification of phytoplankton (Olson et al., 1989; Wilkins et al., 1999)), the addition of fluorescent or fluorogenic stains greatly increases the range of useful information that can be obtained. For example, cell viability is one of the most fundamental properties of a biological cell. Whilst a simple alive/dead distinction may be sufficient in many cases, viability is difficult to define and hence to measure. This leads to the possibility of obtaining different answers from different methods.

Some fluorescent stains are used as viability stains on the basis that they are excluded by intact cell membranes (e.g. propidium iodide); other dyes are used on the basis that they are concentratively accumulated by metabolically-active cells (e.g. rhodamine 123). A third class of viability stains are non-fluorogenic precursors, which are converted to fluorescent products via specific enzymes present in viable cells. Flow cytometry has been used to study viability in a number of microorganisms, but it is generally accepted that no single fluorescent stain will be appropriate for viability measurements in all species or under all conditions (Davey et al., 1999b). In all cases, the measurement of viability by flow cytometry reveals a distribution of fluorescence (stain uptake) and this can be difficult to interpret in terms of a viable/dead answer (see Figure 3). The practical approach is thus to set a threshold value based on the analysis of control samples. The fluorescence intensity of individual cells with respect to the threshold value can then be used as a basis for a viable/ dead distinction. In other circumstances, the distribution of stain uptake can be exploited in studies of the resuscitation of microorganisms from a dormant state. Using conventional microbiological techniques, resuscitation studies have been frustrated by the inability 
to exclude the possibility of re-growth by a subpopulation of viable cells. However, it has been shown that by studying the extent of dye (rhodamine 123) uptake in Micrococcus luteus, it is possible to see a general increase in fluorescence of all (or a significant proportion) of a population, indicating that resuscitation is occurring (Kaprelyants and Kell, 1992, 1993). Furthermore, flow cytometric cell sorting has been used to confirm that those cells that were capable of accumulating rhodamine 123 could be resuscitated in liquid media, whilst the cells with the weakest fluorescence could not be resuscitated under the test conditions (Kaprelyants et al., 1996).

Flow cytometry has also been exploited in studies of survival of Salmonella typhimurium. Rychlik and colleagues (Rychlik et al., 2000) demonstrated that flow cytometry could be used to detect heterogeneity in membrane potential using mutants with known defects. After 28 days starvation in prolonged batch culture, it was shown that a small population of cells had high levels of DNA and RNA and it was proposed that in the original population, natural heterogeneity led to the presence of a small sub-population better adapted for survival. Other workers have studied cultures of $S$. typhimurium after 100+ days and showed that the heterogeneity of the culture increased with prolonged starvation time (Turner et al., 2000).

The applicability of flow cytometry to understanding the heterogeneity of response to an environmental stress has also been demonstrated (Howlett and Avery, 1999). The ability to make multiparametric measurements on individual cells was used to demonstrate that sensitivity to a copper toxicity stress was linked to progression through the cell cycle, and was probably related to cell-cycle dependent fluctuations in basal reactive oxygen species generation.

\section{Antibodies}

The development of monoclonal antibodies has been advantageous to many areas of biological research. Fluorescently-labelled monoclonal antibodies are amenable to detection by flow cytometry. These have found particular use in the detection, identification and enumeration of different mammalian cell types according to the presence or absence of CD markers. A cocktail (or panel) of antibodies with different specificities and compatible fluorescent markers (i.e. without spectral overlap) can be used to identify a variety of cell types in a single assay (see e.g. Baumgarth and Roederer, 2000).

In microbiology, monoclonal antibodies have most often been used to detect a selected cell type against a background of other particulates. There are numerous applications where one may wish to do this, ranging from detection of unwanted microorganisms in foodstuffs (Laplace-Builhé et al., 1993), quality control in industrial fermentations, and the detection of environmental contamination or biowarfare agents (Stopa, 2000). However, antibodies also have a role to play in determinations of physiological characteristics of cells. For example, in the early days of microbial flow cytometry, Steen and colleagues used fluorescently labelled antibodies as part of a flow cytometric method of antigenicity determination (Steen et al., 1982). Antigenicity may vary according to growth conditions, and therefore its measurement is important in the quality control of vaccine production. More recently, flow cytometry was used to determine the heterogeneity of the collagen and fibronectin adhesin densities on the surface of Staphylococcus aureus (Mohamed et al., 2000). These proteins are known to be important in binding of the bacteria to host cells during the infection process and thus their densities on different isolates may be expected to play a role in the pathogenicities of different strains.

Immunodetection can be combined with other types of assays in a multiparametric study of a cell population. Barbesti and colleagues recently showed that a Cy5labelled monoclonal antibody could be combined with SYBR Green I (which stains all cells) and propidium iodide (which stains dead cells), thus performing viability measurement and cell identification in a single assay (Barbesti et al., 2000). This multiparametric approach may be of use where one is interested in the presence of a live pathogen (e.g. to test efficiency of wastewater treatment (Medema et al., 1998; Kato and Bowman, 2002)), or where one wishes to use cell sorting to isolate a potential organism for recovery and growth. In such cases, the presence of a dead organism is likely to be of less interest and thus flow cytometric events relating to it can safely be excluded from further study.

\section{Oligonucleotides}

The phylogenetic heterogeneity of microorganisms can be studied via the variation in ribosomal RNA sequences and a wealth of techniques for the extraction, amplification and analysis of rRNA from microbial populations now exist. Apart from their use in resolving taxonomic debates, oligonucleotides are a useful and specific method of detecting a given cell type against a background of other biologicals. This may be exploited in the required monitoring of the fate of genetically modified organisms (GMO's) following release into the environment.

As described above for antibodies, oligonucleotides may be tagged with a fluorescent marker, thus making them amenable to flow cytometric analysis. Wallner and colleagues used pairs of oligonucleotide probes tagged with either fluorescein or tetramethylrhodamine to detect two different bacterial species in a single sample (Wallner et al., 1993). Furthermore, it has been demonstrated that following flow cytometric cell sorting, cells can be further analysed by PCR-based techniques (Wallner et al., 1997). This approach will allow molecular characterisation of flow cytometrically-identified cohorts of cells, without the requirement for cell growth. This is important since our inability to culture environmental samples may not be entirely due to low viability but simply due to a lack of knowledge of appropriate growth conditions.

\section{Gene Reporter Systems}

Two techniques that enable fluorescence-mediated monitoring of gene expression may be expected to be of particular interest to the molecular biologist. The first of these involves the addition of an appropriate fluorogenic precursor to a cell suspension. Gene expression can then be monitored via conversion of the precursor into fluorescent product in those cells that possess the 
appropriately expressed enzymes (Winson and Davey, 2000). The second approach is more direct in that it involves cloning a gene responsible for production of a fluorescent protein directly to the promoter of interest.

Recently Attfield and colleagues (Attfield et al., 2001) investigated heterogeneity of stress gene expression in Saccharomyces cerevisiae using enhanced green fluorescent protein (EGFP). A sequence of DNA encoding the heat shock and stress elements of the $S$. cerevisiae HSP104 gene was used to express EGFP. EGFP expression was found to increase two-fold as cells progressed from growth on glucose to growth on ethanol in an aerobic batch culture. Elegantly designed experiments exploiting the sorting capability of flow cytometry were performed to obtain 3 subpopulations according to the level of stress response (EGFP expression). Clones isolated from these subpopulations all showed similar heat shock responses, irrespective of which group they were isolated from. Thus, it was concluded that although the genetic background influences the mean level of gene expression of a population, heterogeneity of gene expression in a clonal population may have a physiological basis.

\section{Multiparametric Measurements}

Whilst useful information on the physiological and / or chemical characteristics of cells can be obtained by measuring the fluorescence of a given stain or reporter molecule, a more in-depth understanding of the cell can be obtained by multiparametric measurements. As described above, flow cytometry enables the measurement of multiple characteristics of individual cells. Whilst basic instruments may permit only 2 or 3 signals to be collected simultaneously, the more complex (and expensive) research instruments allow $13+$ parameters to be collected. The problem is no longer one of building hardware capable of making the measurements, but rather the availability of spectrally-distinct dyes with which to label the cells. It is possible to overcome this limitation in some instruments by using time-separated laser interception points, allowing overlapping fluorescence emission spectra to be separated.

The most ambitious multiparametric experimentation in flow cytometry has involved panels of fluorescentlylabelled antibodies against CD markers. These have been used to great effect for studying distributions of white cell populations in various human disease states (see e.g. Helleberg et al., 1997). In comparison, and in part due to the lack of a range of commercial antibodies with different cellular targets, applications of multiparametric flow cytometry of microorganisms is much more limited. Typically only two to three fluorescence parameters plus one or two light scatter parameters are recorded. Nevertheless, even with this more limited approach, multiparametric flow cytometry has been shown to be a very effective means for detecting a given cell type against a background of other biological particles. For example Davey et al (1999a) used cocktails of three fluorescent stains to detect spores of Bacillus globigii in a mixture of other microorganisms. By combining stains with different cellular targets with appropriate multivariate data analysis techniques, the correct identification of $>99 \%$ of the target organisms was possible.
In an alternative approach, Nebe-von-Caron et al. (2000) used immunofluorescent labelling in combination with measurements of cell function to simultaneously determine absolute, relative and viable counts in a complex population. This approach has the advantage that it not only detects a given organism against a background of other particulates, but also provides information on the physiological status of the microorganism, which is very important for environmental screening.

\section{Concluding Remarks}

In conclusion, for the reasons outlined above, the technique of flow cytometry is ideal for the study of heterogeneity in microbial systems. The recent literature shows that the technique has many applications for the study of both natural and 'laboratory-induced' heterogeneity. With the current interest in biodiversity, coupled with the falling cost and improved 'user-friendliness' of flow cytometric instruments, it is likely that applications of flow cytometry for studying heterogeneity will increase.

\section{References}

Andreatta, S., Wallinger, M.M., Posch, T., and Psenner, R. 2001. Detection of subgroups from flow cytometry measurements of heterotrophic bacterioplankton by image analysis. Cytometry 44: 218-225.

Attfield, P.V., Choi, H.Y., Veal, D.A., and Bell, P.J.L. 2001. Heterogeneity of stress gene expression and stress resistance among individual cells of Saccharomyces cerevisiae. Mol. Microbiol. 40: 1000-1008.

Barbesti, S., Citterio, S., Labra, M., Baroni, M.D., Neri, M.G., and Sgorbati, S. 2000. Two and three-color fluorescence flow cytometric analysis of immunoidentified viable bacteria. Cytometry 40: 214-218.

Baumgarth, N., and Roederer, M. 2000. A practical approach to multicolor flow cytometry for immunophenotyping. J. Immunol. Methods 243: 77-97.

Bell, P.J.L., Deere, D., Shen, J., Chapman, B., Bissinger, P.H., Attfield, P.V., and Veal, D.A. 1998. A flow cytometric method for rapid selection of novel industrial yeast hybrids. Appl. Environ. Microbiol. 64: 1669-1672.

Betz, J.W., Aretz, W., and Hartel, W. 1984. Use of flow cytometry in industrial microbiology for strain improvement programs. Cytometry 5: 145-150.

Bull, A.T., Ward, A.C., and Goodfellow, M. 2000. Search and discovery strategies for biotechnology: The paradigm shift. Microbiology and Molecular Biology Reviews 64: 573-606.

Campbell, A., Robertson, L., and Smith, H. 1993. Novel methodology for the detection of Cryptosporidium parvum-a comparison of cooled charge coupled devices (CCD) and flow cytometry. Water Science and Technology 27: 89-92.

Chrétiennot-Dinet, M.J., Courties, C., Vaquer, A., Neveux, J., Claustre, H., Lautier, J., and Machado, M.C. 1995. A new marine picoeucaryote-Ostreococcus tauri gen. et. sp. nov. (Chlorophyta, Prasinophyceae). Phycologia 34: 285-292.

Davey, H.M., Jones, A., Shaw, A.D., and Kell, D.B. 1999a. 
Variable selection and multivariate methods for the identification of microorganisms by flow cytometry. Cytometry 35: 162-168.

Davey, H.M., Kaprelyants, A.S., Weichart, D.H., and Kell, D.B., 1999b. Approaches to the estimation of microbial viability using flow cytometry, Current Protocols in Cytometry. Wiley, New York, p. 11.13.11-11.13.20.

Goodacre, R., and Kell, D.B. 1993. Rapid and quantitative analysis of bioprocesses using pyrolysis massspectrometry and neural networks-application to indole production. Analytica Chimica Acta 279: 17-26.

Helleberg, C., Knudsen, H., Hansen, P., Nikolajsen, K., Kjaersgaard, E., Ralfkiaer, E., and Johnsen, H. 1997. CD34+ megakaryoblastic leukaemic cells are CD38-, but CD61 + and glycophorin A+: improved criteria for diagnosis of AML-M7? Leukemia 11: 830-834.

Hewitt, C.J., Nebe-Von Caron, G., Axelsson, B., McFarlane, C.M., and Nienow, A.W. 2000. Studies related to the scaleup of high-cell-density $E$. coli fed-batch fermentations using multiparameter flow cytometry: Effect of a changing microenvironment with respect to glucose and dissolved oxygen concentration. Biotechnol. Bioeng. 70: 381-390.

Howlett, N.G., and Avery, S.V. 1999. Flow cytometric investigation of heterogeneous copper-sensitivity in asynchronously grown Saccharomyces cerevisiae. FEMS Microbiol. Lett. 176: 379-386.

Kaprelyants, A.S., and Kell, D.B. 1992. Rapid assessment of bacterial viability and vitality using rhodamine 123 and flow cytometry. J. Appl. Bacteriol. 72: 410-422.

Kaprelyants, A.S., and Kell, D.B. 1993. Dormancy in stationary-phase cultures of Micrococcus luteus: flow cytometric analysis of starvation and resuscitation. Appl. Environ. Microbiol. 59: 3187-3196.

Kaprelyants, A.S., Mukamolova, G.V., Davey, H.M., and Kell, D.B. 1996. Quantitative analysis of the physiological heterogeneity within starved cultures of Micrococcus luteus using flow cytometry and cell sorting. Appl. Environ. Microbiol. 62: 1311-1316.

Kato, S., and Bowman, D.D. 2002. Using flow cytometry to determine the viability of Cryptosporidium parvum oocysts extracted from spiked environmental samples in chambers. Parasitol. Res. 88: 326-331.

Laplace-Builhé, C., Hahne, K., Hunger, W., Tirilly, Y., and Drocourt, J.L. 1993. Application of flow cytometry to rapid microbial analysis in food and drinks industries. Biol. Cell 78: 123-128.

Lloyd, D., 1993. Flow cytometry: a technique waiting for microbiologists. In: Lloyd, D. (Ed.), Flow cytometry in microbiology. Springer-Verlag, London, p. 1-9.

Maksimow, M., Hakkila, K., Karp, M., and Virta, M. 2002. Simultaneous detection of bacteria expressing gfp and dsred genes with a flow cytometer. Cytometry 47: 243247.

Medema, G.J., Schets, F.M., Ketelaars, H., and Boschman, G. 1998. Improved detection and vital staining of Cryptosporidium and Giardia with flow cytometry. Water Science and Technology 38: 61-65.

Mohamed, N., Visai, L., Speziale, P., and Ross, J.M. 2000. Quantification of Staphylococcus aureus cell surface adhesins using flow cytometry. Microb. Pathog. 29: 357361.
Nebe-von-Caron, G., Stephens, P., and Badley, R.A. 1998. Assessment of bacterial viability status by flow cytometry and single cell sorting. J. Appl. Microbiol. 84: 988-998.

Nebe-von-Caron, G., Stephens, P.J., Hewitt, C.J., Powell, J.R., and Badley, R.A. 2000. Analysis of bacterial function by multi-colour fluorescence flow cytometry and single cell sorting. J. Microbiol. Meth. 42: 97-114.

Okinaka, R.T., Cloud, K., Hampton, O., Hoffmaster, A.R., Hill, K.K., Keim, P., Koehler, T.M., Lamke, G., Kumano, S., Mahillon, J., Manter, D., Martinez, Y., Ricke, D., Svensson, R., and Jackson, P.J. 1999. Sequence and organization of $\mathrm{pXO1}$, the large Bacillus anthracis plasmid harboring the anthrax toxin genes. J. Bacteriol. 181: 65096515.

Olson, R.J., Zettler, E.R., and Anderson, O.K. 1989. Discrimination of eukaryotic phytoplankton cell-types from light scatter and autofluorescence properties measured by flow cytometry. Cytometry 10: 636-643.

Paustian, T., 2002. Microbiology web textbook (http:// www.bact.wisc.edu/microtextbook/index.html). Department of Bacteriology, University of WinconsinMadison.

Rychlik, I., Cardova, L., Sevcik, M., and Barrow, P.A. 2000. Flow cytometry characterisation of Salmonella typhimurium mutants defective in proton translocating proteins and stationary-phase growth phenotype. J. Microbiol. Meth. 42: 255-263.

Shapiro, H.H. 2000. Microbial analysis at the single-cell level: tasks and techniques. J. Microbiol. Meth. 42: 3-16. Shapiro, H.M., 1995. Practical flow cytometry (3rd edition). Alan R. Liss Inc., New York.

Steen, H.B., Boye, E., Skarstad, K., Bloom, B., Godal, T., and Mustafa, S. 1982. Applications of flow cytometry on bacteria: cell cycle kinetics, drug effects and quantitation of antibody binding. Cytometry 2: 249-257.

Stopa, P.J. 2000. The flow cytometry of Bacillus anthracis spores revisited. Cytometry 41: 237-244.

Turner, K., Porter, J., Pickup, R., and Edwards, C. 2000. Changes in viability and macromolecular content of longterm batch cultures of Salmonella typhimurium measured by flow cytometry. J. Appl. Microbiol. 89: 90-99.

Vives-Rego, J., Lebaron, P., and Nebe-von Caron, G. 2000. Current and future applications of flow cytometry in aquatic microbiology. FEMS Microbiol. Rev. 24: 429-448. Wallner, G., Fuchs, B., Spring, S., Beisker, W., and Amann, R. 1997. Flow sorting of microorganisms for molecular analysis. Appl. Environ. Microbiol. 63: 4223-4231.

Wallner, H., Amann, R., and Beisker, W. 1993. Optimizing fluorescent in situ hybridization with rRNA-targeted oligonucleotide probes for flow cytometric identification of microorganisms. Cytometry 14: 136-143.

Wilkins, M.F., Boddy, L., Morris, C.W., and Jonker, R.R. 1999. Identification of phytoplankton from flow cytometry data by using radial basis function neural networks. Appl. Environ. Microbiol. 65: 4404-4410.

Winson, M.K., and Davey, H.M. 2000. Flow cytometric analysis of microorganisms. Methods: Methods in Enzymology 21: 231-240. 


\section{Further Reading}

Caister Academic Press is a leading academic publisher of advanced texts in microbiology, molecular biology and medical research. Full details of all our publications at caister.com

- MALDI-TOF Mass Spectrometry in Microbiology Edited by: M Kostrzewa, S Schubert (2016) www.caister.com/malditof

- Aspergillus and Penicillium in the Post-genomic Era Edited by: RP Vries, IB Gelber, MR Andersen (2016) www.caister.com/aspergillus2

- The Bacteriocins: Current Knowledge and Future Prospects Edited by: RL Dorit, SM Roy, MA Riley (2016)

www.caister.com/bacteriocins

- Omics in Plant Disease Resistance Edited by: V Bhadauria (2016) www.caister.com/opd

- Acidophiles: Life in Extremely Acidic Environments Edited by: R Quatrini, DB Johnson (2016) www.caister.com/acidophiles

- Climate Change and Microbial Ecology: Current Research and Future Trend

Edited by: J Marxsen (2016)

www.caister.com/climate

- Biofilms in Bioremediation: Current Research and Emerging Technologies

Edited by: G Lear (2016)

www.caister.com/biorem

- Microalgae: Current Research and Applications Edited by: MN Tsaloglou (2016) www.caister.com/microalgae

- Gas Plasma Sterilization in Microbiology: Theory, Applications, Pitfalls and New Perspectives Edited by: H Shintani, A Sakudo (2016) www.caister.com/gasplasma

- Virus Evolution: Current Research and Future Directions Edited by: SC Weaver, M Denison, M Roossinck, et al. (2016) www.caister.com/virusevol

- Arboviruses: Molecular Biology, Evolution and Control Edited by: N Vasilakis, DJ Gubler (2016) www.caister.com/arbo

- Shigella: Molecular and Cellular Biology Edited by: WD Picking, WL Picking (2016) www.caister.com/shigella

-Aquatic Biofilms: Ecology, Water Quality and Wastewater Treatment

Edited by: AM Romaní, H Guasch, MD Balaguer (2016)

www.caister.com/aquaticbiofilms

- Alphaviruses: Current Biology

Edited by: S Mahalingam, L Herrero, B Herring (2016)

www.caister.com/alpha

- Thermophilic Microorganisms

Edited by: F Li (2015)

www.caister.com/thermophile
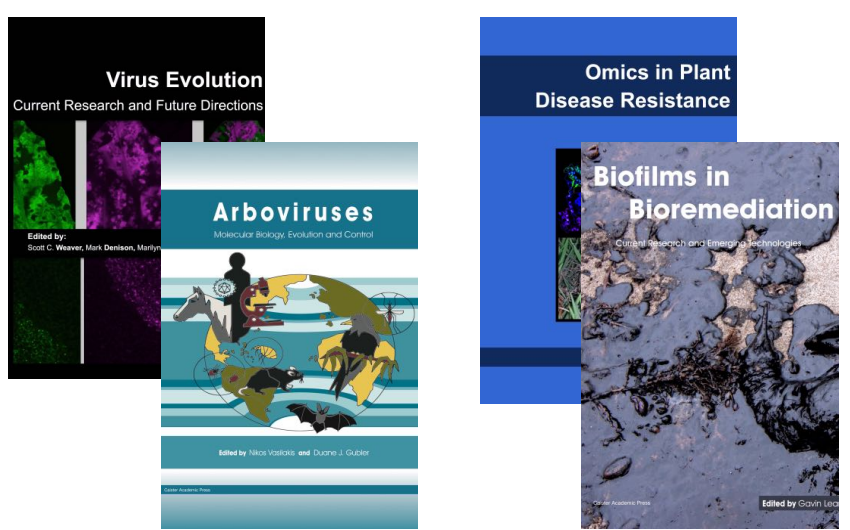
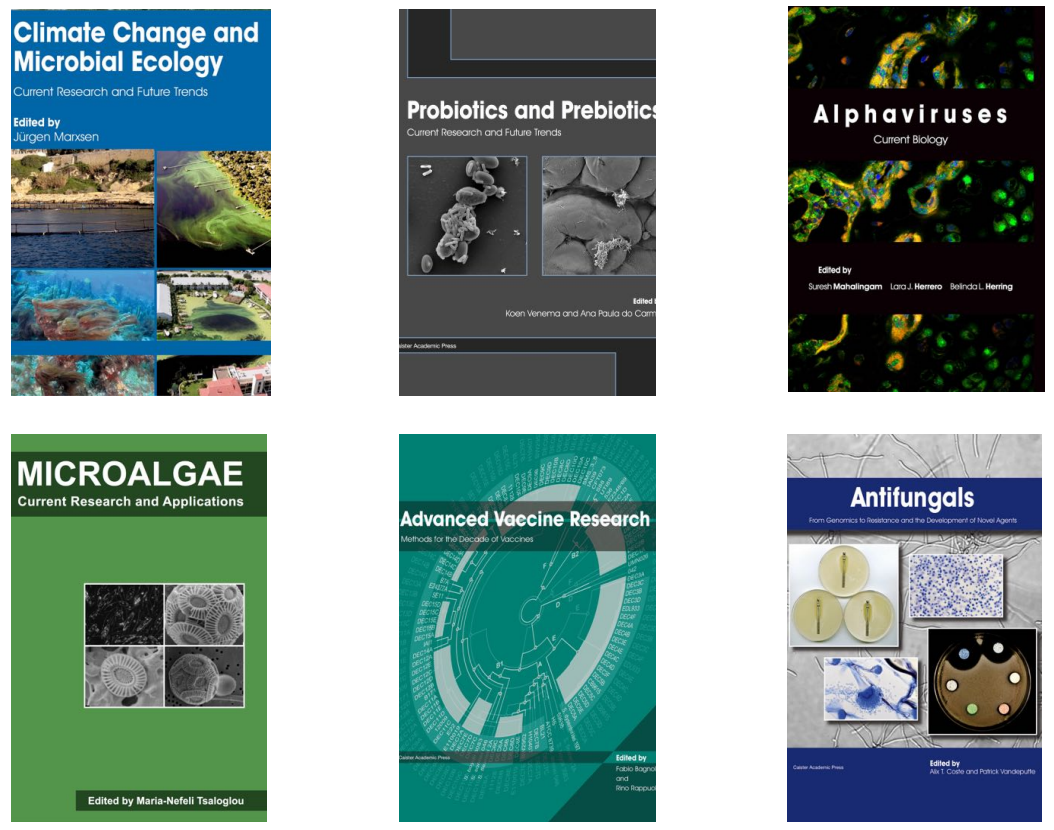

- Flow Cytometry in Microbiology: Technology and Applications Edited by: MG Wilkinson (2015) www.caister.com/flow

- Probiotics and Prebiotics: Current Research and Future Trends Edited by: K Venema, AP Carmo (2015) www.caister.com/probiotics

- Epigenetics: Current Research and Emerging Trends Edited by: BP Chadwick (2015) www.caister.com/epigenetics2015

- Corynebacterium glutamicum: From Systems Biology to Biotechnological Applications

Edited by: A Burkovski (2015)

www.caister.com/cory2

- Advanced Vaccine Research Methods for the Decade of Vaccines

Edited by: F Bagnoli, R Rappuoli (2015)

www.caister.com/vaccines

- Antifungals: From Genomics to Resistance and the Development of Novel Agents

Edited by: AT Coste, P Vandeputte (2015)

www.caister.com/antifungals

- Bacteria-Plant Interactions: Advanced Research and Future Trends Edited by: J Murillo, BA Vinatzer, RW Jackson, et al. (2015) www.caister.com/bacteria-plant

\section{- Aeromonas}

Edited by: J Graf (2015)

www.caister.com/aeromonas

- Antibiotics: Current Innovations and Future Trends

Edited by: S Sánchez, AL Demain (2015)

www.caister.com/antibiotics

- Leishmania: Current Biology and Contro Edited by: S Adak, R Datta (2015) www.caister.com/leish2

- Acanthamoeba: Biology and Pathogenesis (2nd edition) Author: NA Khan (2015)

www.caister.com/acanthamoeba2

- Microarrays: Current Technology, Innovations and Applications Edited by: Z He (2014)

www.caister.com/microarrays2

- Metagenomics of the Microbial Nitrogen Cycle: Theory, Methods and Applications

Edited by: D Marco (2014)

www.caister.com/n2 